\title{
THE RELATIONSHIP BETWEEN SELECTION OF FIRST COMPLEMENTARY FOODS WITH FOOD PREFERENCES IN INFANTS AND TODDLERS
}

\author{
Esty Puji Rahayu' ${ }^{1)}$, Annif Munjidah'2) \\ Email: esty@unusa.ac.id \\ ${ }^{1}$ Prodi S1 Kebidanan Universitas NU Surabaya J1. SMEA No. 57 Wonokromo, Surabaya \\ ${ }^{2}$ Prodi D3 Kebidanan Universitas NU Surabaya J1. SMEA No. 57 Wonokromo, Surabaya
}

\section{Article Information}

Received:

October 10, 2019

Revised:

December 27, 2019

Accepted:

January 19, 2020

Available online:

January 23, 2020

\begin{abstract}
Giving complementary food at the right time is very beneficial for meeting the nutritional needs and growth and development of infants. However, if the child is difficult to eat or choose to eat, the child's growth will be disrupted It also becomes stressful for his parents. Food picking habits are included in the term food preference. In addition to being picky about food, rejection of certain foods is also included in this term. In this study, we want to know the relationship between First complementary food selection with Food Preference in infants and toddlers. The research design used is correlational analytic with a retrospective approach. The population is mothers who have babies and toddlers under the age of 5 years in the Rw 11 region of Jagir sub-district. The sampling technique uses purposive sampling technique. From data analysis with the Spearman test. in this study the selection of the first complementary food and Food Preference has a significant relationship with $\mathrm{p}$ value 0.044 . It is expected that the results of this study will make mothers who have toddlers understand even more about choosing the right complemetary foodnamely with a complete menu that we feel we call a 4 star menu.
\end{abstract}

Keywords: complementary food, picky eater, food preference

\section{Introduction}

Growth is a critical component in assessing nutritional status and can be used as an indicator of the health/wellbeing of individuals and populations. Growth disruption is still a health problem in Indonesia. Preliminary data from the 2008 National Health Survey showed that the prevalence of short stature was $37 \%$ in children under five years of age due to lack of nutritional supply at the time of growth, as well as birth weight below the standard of 2.5 kilograms. According to the 2005 Susenas results, the prevalence of underfive children was $28 \%$, while (wasting) was $15.5 \%$. The determinants of a child's quality of growth are intrinsic factors (genetic, congenital, and hormonal disorders) and extrinsic factors (quality and quantity of nutrition, chronic diseases, and emotional disorders $)^{[1]}$.

Based on the 2017 Nutrition Status Monitoring conducted by the Ministry of Health, infants under five years old (Toddler) who experienced nutritional problems in 2017 reached $17.8 \%$, the same as the previous year, and while stunting reached $29.6 \%$. A study in Chicago reported that eating behavior problems most often found in infants were not always hungry at mealtime 
(33\%) while eating behavior problems in toddlers were not always hungry at mealtime $(52 \%)$, trying to end eating after several mouthfuls (42\%), "picky eating" (35\%), and the strength of particular food preferences $(33 \%)^{[2]}$. A study conducted by Sudibyo Supardi (2015) showed that the prevalence of eating difficulties was $33.6 \%{ }^{[3]}$

Complementary feeding at the right time is very beneficial for meeting the nutritional needs and growth and development of infants. The prevalence of stunting in toddlers with complaints of difficulty eating was $33 \%$. The incidence of stunting is related to the history of non-exclusive breastfeeding and the early age of initiation of supplementary breastfeeding earlier or later and also associated with unfortified breastfeeding supplementation in children. ${ }^{[4]}$

Achieving optimal growth is a dream for every parent. However, if the child is difficult to eat or picky to eat, it can cause growth disorders. It also causes stress for parents. Food picking habits are included in the term food preference. In addition to being picky about food, rejection of certain foods is also included in this term. Food preferences do have a broad spectrum, ranging from picky eaters to selective eaters. ${ }^{[1]}$

According to Prof. Dr. Rini Sekartini, SpA, the picky eater is a disorder of eating behavior in children related to the psychological development of growth and is characterized by the condition of children reluctant to try new types of food. Usually, the condition of picky eaters is due to a lack of food variation in children ${ }^{[3]}$.

The first complementary food menu greatly influences the pattern of eating in subsequent children. Generally, mothers give the first complementary foods at the age of six months by giving mashed bananas or cereals. Even though at this age, they are allowed to provide a complete menu of complementary foods with various food flavors.

One of the causes of picky eaters included in the food preference is the selection of the complementary food menu. A study conducted at one kindergarten in Bekasi showed that picky eaters due to inaccurate parents in providing complementary foods. When starting to get complementary foods, the eating schedule provided was not consistent. Similarly, the menu it provides. Some children only get softtextured foods such as porridge until they were two years old ${ }^{[5]}$. An observational study conducted at the Sidotopo Community Health Center Surabaya, with respondents from mothers who have toddlers obtained the results that children with a history of not getting exclusive breastfeeding and a history of inappropriate complementary feeding tend to have picky eater behavior. Children's eating behavior will affect the nutritional status of children ${ }^{[6]}$.

Various efforts need to be made to reduce the incidence of a picky eater and optimize children's growth. In addition to applying the rules of children's eating, various efforts can also be made. The WHO Global Strategy for Feeding Infant and Young Children in 2003 recommended that the provision of complementary foods meet four conditions, which are timely, adequate, safe, and given in the right way. This study aims to analyze the relationship between the selection of first complementary foods with the Food Preference event, whereas Food preference consists of selective eater and picky eater.

\section{Method}

This study used a correlational analytic research design that is connecting research variables using statistical tests. The approach used retrospectively to the population of mothers who have babies and toddlers under the age of 5 years in 
the RW 11 region of Jagir Village. The sampling technique used a purposive sampling technique where sampling that meets the criteria of the study were willing to be a respondent; infants and toddlers were not suffering from chromosomal abnormalities and had disabilities - a sample of 39 respondents. The study was conducted for two months. The study was conducted by filling out questionnaires, interviews, and observations. The research instrument used was a questionnaire sheet given to respondents about general data of respondents, data about accompanying food, and eating problems in children. Data collection was done by recapitulating the observations, then analyzing the data using the Chi-Square test.

\section{Results and discussion}

a. Characteristics of respondents based on the age of the child

The characteristics of respondents based on the age of the child will be presented in the frequency distribution table as follows:

Table 1 Frequency Distribution of Respondents According to The Age of The Child

\begin{tabular}{cccc}
\hline No & Age (month) & f & \% \\
\hline 1. & $6-12$ & 14 & 35.89 \\
2. & $13-18$ & 3 & 7.69 \\
3. & $19-24$ & 3 & 7.69 \\
4. & $25-36$ & 7 & 17.95 \\
5. & $37-48$ & 9 & 23.09 \\
6. & $49-60$ & 3 & 7.69 \\
& Total & 39 & 100 \\
\hline
\end{tabular}

In this study, respondents were mothers who have toddlers aged six months to 5 years. Table 1 shows that most children were 6-12 months (35.89\%) and children at an early age to know complementary foods. Early breastfeeding complementary foods before the age of six months will cause infants vulnerable to infectious and allergic diseases, which can lead to malnutrition and growth disorders. ${ }^{[5]}$

b. Characteristics of Respondents Based on The Mother's Education Characteristics of respondents based on the mother's education will be presented in the frequency distribution table as follows:

Table 2 Frequency Distribution of Respondents According to The Mother's Last Education

\begin{tabular}{clcc}
\hline No & \multicolumn{1}{c}{ Education } & f & $\mathbf{( \% )}$ \\
\hline 1. & Elementary School & 4 & 10.26 \\
2. & Junior High School & 7 & 17.95 \\
3. & Senior / Vocational & 18 & 46.15 \\
& High School & & \\
4. & Diploma & 2 & 5.13 \\
5. & Bachelor & 7 & 17.95 \\
6. & Master & 1 & 2.56 \\
& $\quad$ Total & 39 & 100 \\
\hline
\end{tabular}

Table 2 shows that most mothers with a high school education were $46.15 \%$. Education can affect a person's learning process; the higher one's education will be easier to accept existing information. The more information that comes in, the more knowledge gained, including information about health. The higher one's education, the higher one's knowledge will be. ${ }^{[7]}$

The process of supplementary feeding is very influential in the child's growth and development. The method, processing, and selection of complementary foods are also influenced by the mother's knowledge of complementary foods. In a study conducted on mothers who have babies under two years old, aged 6-24 months, in Kestalan Subdistrict, Banjarsari Subdistrict, Surakarta, the results showed that there was a relationship between maternal knowledge of complementary foods with maternal 
behavior regarding feeding the complimentary food. [8] In this study, most mothers had a high school education, but even though they have secondary education, mothers can still get information about complementary foods from the internet. Even so, there are not many mothers who are ignorant of the children's nutritional needs, especially regarding the selection and proper processing of complementary foods.

c. Characteristics of Respondents Based on The Selection of First Complementary Foods

Respondent characteristics based on the selection of first complementary foods will be presented in the frequency distribution table as follows:

Table 3 Frequency Distribution of Respondents According to The Selection of The First Complementary Food Menu

\begin{tabular}{llcc}
\hline No & $\begin{array}{c}\text { Complementary } \\
\text { Food Menu }\end{array}$ & f & $\mathbf{( \% )}$ \\
\hline 1. & Single Menu & 15 & 38.46 \\
2. & Porridge flour & 2 & 5.13 \\
3 & Instant Porridge & 12 & 30.77 \\
4 & A 4-star homemade & 10 & 25.64 \\
\hline & Total & 39 & 100 \\
\hline
\end{tabular}

Table 3 shows that most mothers provided side dishes with a single menu such as mashed bananas, or $38.46 \%$ steamed pumpkin. Of the various types of complementary foods ranging from a single menu, flour porridge, instant porridge, and a 4-star menu, in this study, most mothers chose a single menu for children's first complementary foods. A single menu was a menu consisting of only one food item. ${ }^{[9]}$ Examples of single menus were puree bananas, potatoes, pumpkin. The first typical complementary food given to babies in Indonesia is bananas and rice flour mixed with breast milk. Both of these foods can meet the lack of energy because a banana measuring $15 \mathrm{~cm}$ with a weight of 80 grams can contribute $90 \mathrm{kcal}$, and $28 \mathrm{~g}$ of rice flour contributes $102 \mathrm{kcal}$. If it refers to the energy needs of a sixmonth baby boy weighing $7 \mathrm{~kg}$ and body length $66 \mathrm{~cm}$, the energy requirements of breast milk and complementary food per day is around $770 \mathrm{kcal}$, with a ratio of around $200 \mathrm{kcal}$ fulfilled by a complementary food and the rest by breast milk. That is, consumption of $770-800 \mathrm{ml}$ of breast milk plus one portion of rice flour @ 28 grams plus one banana meets the baby's energy needs, but not for iron, protein, and zinc $(\mathrm{Zn})^{[1]}$. The right complementary foods are rich in energy, protein, micronutrients, readily eaten by children, preferably from local and affordable food. A 4star food menu is made by including foods from the staple, vegetable and fruit categories, nuts, and animal foods. $^{[10]}$

\section{d. Respondent Characteristics}

\section{Based on Food Preference}

Respondent characteristics based on food preference will be presented in the frequency distribution table as follows:

Table 4 Frequency distribution of respondents according to children's eating problems

\begin{tabular}{lllllll}
\hline \multirow{2}{*}{ No } & Eating & \multicolumn{2}{c}{ Yes } & \multicolumn{2}{c}{ No } & \multirow{2}{*}{ Total } \\
\cline { 3 - 6 } & Problems & f & $\mathbf{\%}$ & f & \% & \\
\hline 1. & Picky & 10 & 25.64 & 29 & 74.36 & 100 \\
& $\begin{array}{l}\text { Eater } \\
\text { 2. }\end{array}$ & & & & & \\
& Eelective & 22 & 56.41 & 17 & 43.59 & 100 \\
\hline
\end{tabular}

Table 4 shows the majority of children who experienced picky eating. In addition to affecting the growth and development of 
children, the choice of the child's first complementary food menu will also affect eating problems in children. Multicentre research conducted by UKK Nutrition and Metabolic Diseases in 2012-2013 in 11 pediatrician specialist educational institutions covering 1116 toddlers shows that eating problems can be classified as inappropriate feeding practices, small eaters, parental misperception, and food preferences (picky eater and selective eater). ${ }^{[1]}$

e. Relationship of First Complementary Food with Picky and Selective Eater

The relationship between the selection of the first complementary foods with Picky Eater can be seen in the table below:

Table 5 Cross-distribution of first complementary foods with picky eaters

\begin{tabular}{lcccccc}
\hline \multicolumn{1}{c}{ First } \\
$\begin{array}{c}\text { Complementary } \\
\text { Food }\end{array}$ & F & \% & f & \% & f & $\%$ \\
\hline Single Menu & 2 & 5.13 & 13 & 33.33 & 15 & 100 \\
Porridge flour & 0 & 0 & 2 & 5.13 & 2 & 100 \\
Instant Porridge & 3 & 7.69 & 9 & 23.08 & 12 & 100 \\
A 4-star & 5 & 12.82 & 5 & 12.82 & 10 & 100 \\
homemade & & & & & & \\
$\quad$ Total & 10 & 25.64 & 29 & 74.36 & 39 & 100 \\
\hline
\end{tabular}

Based on the results of the statistical test with the Spearman test results obtained p-value 0.044 , which means that there is a significant relationship between the selection of the first complementary food with Picky Eater. Utami (2016), stated that picky eater behavior was caused due to inaccurate parents in giving complementary food. When starting to get complementary foods, breastfeeding provided inconsistently. Similarly, the menu it provides. Some children only get soft-textured foods such as porridge until he is two years old..$^{[5]}$

The relationship between the selection of the first complementary menu with selective eater can be seen in the table below:

Table 6 Cross-distribution of First Complementary Foods with Selective Eater

\begin{tabular}{ccccccc}
\hline $\begin{array}{c}\text { First } \\
\text { Complementary } \\
\text { Foods }\end{array}$ & \multicolumn{2}{c}{ Ya } & \multicolumn{2}{c}{ Tidak } & \multicolumn{2}{c}{ Total } \\
\cline { 2 - 7 } & $\mathbf{f}$ & $\mathbf{\%}$ & $\mathbf{f}$ & $\boldsymbol{\%}$ & $\mathbf{f}$ & $\boldsymbol{\%}$ \\
\hline Single Menu & 7 & 17.95 & 8 & 20.51 & 15 & 38.4 \\
& & & & & & 6 \\
Porridge flour & 0 & 0 & 2 & 5.13 & 2 & 5.13 \\
Instant & 6 & 15.38 & 6 & 15.38 & 12 & 30.7 \\
Porridge & & & & & & 6 \\
A 4-star & 6 & 15.38 & 4 & 10.27 & 10 & 25.6 \\
homemade & & & & & & 5 \\
\hline Total & 19 & 48.71 & 20 & 51.29 & 39 & 100 \\
\hline
\end{tabular}

Besides picky eater, the selective eater is part of the Food Preference in children. Selective eater is a child who rejects all types of food in certain food groups, for example, rejecting all food sources of protein. Selective eater is a pathological food preference because it causes a loss of intake of one of the four food groups so that children are at risk of experiencing micronutrient deficiencies or certain micronutrients. ${ }^{[1]}$

After analyzing the data with the Spearman test, the results show that there is no significant relationship between the selection of complementary foods with Selective eater with a p-value of 0.725 . Selective eater generally occurs in children with certain developmental disorders, such as autistic spectrum disorder, posttraumatic feeding disorder, swallowing disorders, oromotor delays, and gastrointestinal disorders ${ }^{[1]}$. While in this study, none of the respondents experienced 
ASD or oromotor disorders, but there were still some children who experienced selective eater. Children with autism spectrum disorders insist on using the same tools or plates and insist on preparing food in specific ways significantly more often than other children. Children with special needs have problems with food vomiting and oral motor delays than other children. Children without special needs have more anxiety or obsessive-compulsive behavior problems than other children. ${ }^{[11]}$

Picky eater and selective eater are problems that need to be addressed as quickly as possible because otherwise, they will affect the child's growth and development. Children with eating problems later will also contribute to the prevalence of stunting and malnutrition in Indonesia. Various efforts need to be made to suppress food preferences in children. One of them is by educating mothers about the importance of complementary foods with adequate nutrition, selection of appropriate complementary foods, information on how to provide food and innovations about complementary food recipes to increase appetite.

\section{Conclusion}

Based on this study, it can be concluded that the selection of the first complementary food and the Food Preference that is Picky Eater has a significant relationship with $p$-value 0.044 . The advice given is that the community, especially mothers who have toddlers, provide their first complimentary food according to WHO recommendations, which is a complete menu that we usually call a 4-star menu.

\section{Acknowledgments}

All authors are very grateful to LPPM UNUSA for helping to complete this study. Secondly, we express our gratitude to the respondents in the Jagir Surabaya village, who was pleased to be interviewed. This study was limited to one RW area, and it expected that other studies would be able to conduct a study in a broader scope.

\section{References}

[1] Ikatan Dokter Anak Indonesia. Pendekatan Diagnosis dan Tata Laksana Masalah Makan pada Batita di Indonesia. Jakarta: UKK Nutrisi dan Penyakit Metabolik. 2014.

[2] Ikatan Dokter Anak Indonesia. Rekomendasi Praktik Pemberian Makan Berbasis Bukti pada Bayi dan Batita di Indonesia untuk Mencegah Malnutrisi. Jakarta: UKK Nutrisi dan Penyakit Metabolik. 2015.

[3] Anna, Lusia Kus. Pengaruh Pola Makan "Picky Eater" pada Kesehatan Anak. Jakarta: Kompas. 2018.

[4] Saputri, Diah Komang. Prevalensi stunting pada toddler dengan keluhan sulit makan dan hubungannya dengan asupan nutrisi pada satu tahun pertama. Medicina, Volume 50, Number 2: 370-376. 2019.

[5] Utami, Fitria Budi. Picky Eater Pada Anak Kota: Studi Kasus Anak Usia 3-4 Tahun. Jurnal Sosioreligi. 2016. Volume 14 Nomor 2, Edisi September.

[6] Cahyani, Arian Susanti Dewi. Hubungan Riwayat Asi Eksklusif, Riwayat Pemberian Makanan Pendamping Asi (Mp-Asi) Dengan Persepsi Ibu Terhadap Perilaku Picky Eater Dan Status Gizi Pada Anak Usia 12-36 Bulan Di Puskesmas Sidotopo Surabaya. 
Skripsi. Surabaya: Universitas Airlangga. 2019.

[7] Widayatun. Ilmu Perilaku. Jakarta: Rineka Cipta. 2004.

[8] Mawarni, Siti. Hubungan Pengetahuan Ibu Tentang Mp-Asi Dengan Perilaku Pemberian MPASI Dan Status Gizi Pada Baduta Usia 6-24 Bulan Di Kelurahan Kestalan Kecamatan Banjarsari Kota Surakarta. Skripsi thesis. Universitas Muhammadiyah Surakarta. 2013.

[9] Pusparini,Cahyani Endah. Penyuluhan Pemberian Mpasi Menu Tunggal Menurut Who Dengan Media Buku Saku Untuk Pengetahuan Ibu Dan Penerapan Pada Bayi Umur 6 Bulan Di Bpm Suryati Puring. Karya Tulis Ilmiah. Gombong : Sekolah Tinggi Ilmu Kesehatan Muhammadiyah Gombong. 2018.

[10] Saputri, Frada. Penerapan Penyuluhan tentang MP ASI terhadap Praktek Pemberian MP ASI 4 Bintang pada Bayi Umur 612 Bulandi BPM Jemanis Kabupaten Kebumen. The 10thUniversity Research Colloqium Sekolah Tinggi Ilmu Kesehatan Muhammadiyah Gombong. 2019.

[11] Keith E. Williams, Bridget G. Gibbons, and Kimberly A. Schreck. Comparing Selective Eaters with and Without Developmental Disabilities. Journal of Developmental and Physical Disabilities. 2005. Vol. 17, No. 3 